\title{
Employee Satisfaction: Determinants and Its Effect on Performance
}

\author{
Nurhidayati $^{1}$; Nunik Kusnilawati ${ }^{2}$; Aprih Santoso ${ }^{3 *}$ \\ ${ }_{1,2,3}$ Departemen Manajemen, FE Universitas Semarang \\ Email Addres: \\ nurhidayati@usm,ac,id $;$;nunik_k@usm.ac.id ${ }^{2}$;aprihsantoso@usm.ac.id ${ }^{3}$ \\ ${ }^{*}$ Corresponding author
}

\begin{abstract}
This study aims to examine the effect of competence, motivation, education on satisfaction and the effect of competence, motivation, education on performance and satisfaction on performance. The research method uses quantitative methods and the sample consists of 96 people consisting of employees who graduated from the University of Semarang who graduated a maximum of 3 years. The analytical tool used is SEM PLS. The result of the analysis is that competence has no effect on satisfaction, but does affect performance. Motivation and education affect satisfaction and performance, and satisfaction affects performance.
\end{abstract}

Keywords: Competence, Motivation, Education, Satisfaction, Performance.

\begin{abstract}
Abstrak: Penelitian bertujuan meneliti pengaruh kompetensi, motivasi, pendidikan terhadap kepuasan dan pengaruh kompetensi, motivasi, pendidikan terhadap kinerja serta kepuasan terhadap kinerja. Metode penelitian menggunakan metode kuantitaf dan sampel berjumlah 96 orang yang terdiri dari karyawan lulusan Universitas Semarang yang lulus maksimal 3 tahun. Alat analisis yang digunakan adalah SEM - PLS. Hasil analisis adalah kompetensi tidak berpengaruh terhadap kepuasan, tetapi berpengaruh terhadap kinerja. Motivasi dan pendidikan berpengaruh terhadap kepuasan dan kinerja, serta kepuasan berpengaruh terhadap kinerja.
\end{abstract}

Kata kunci: Kompetensi, Motivasi, Pendidikan, Kepuasan, Kinerja.

\section{INTRODUCTION}

The success of a company can be achieved by paying attention to many factors, one of which is the key to success is employee performance. This is because proper employee management will not only provide benefits for the company, but will also encourage employees to improve their performance for the better. The company is always trying to find ways to maintain and manage employee performance so that it can be maximized. Employee performance is an individual matter, because each employee has a different level of qualification and different performance in relation to his duties. Management can 
measure employee performance based on their performance. Performance is an action, not an event, Performance action itself consists of many components and not a direct result. Basically, performance is something that is individual, because every employee has a different ability to do his job.

Many factors affect performance, including: competence (Kartika and Sugiarto, 2014); (Manik and Wiarah, 2014); (Deswarta, 2017); (Alam et al., 2021) and (Darman and Adha, 2021), motivation (Sedarmayanti, 2017); (Mangkunegara, 2015); (Gardjito et al., 2014); (Rahsel, 2016); (Razak, 2021); (Alam et al., 2021) and (Verawati et al., 2021), and education (Sedarmayanti, 2017; Juliana et al., 2015 and Mandang et al, 2017), and satisfaction (Sumampouw et al, 2017; Indrawati, 2013).

Competence according to (Spencer and Spencer, 1993) is a characteristic that underlies a person and is related to the effectiveness of individual performance in his work. (Kartika and Sugiarto, 2014), (Manik and Wiarah, 2014); (Deswarta, 2017); (Alam et al., 2021) and (Darman and Adha, 2021) who use competence have an effect on performance, on the contrary (Septiyani and Sanny, 2013); (Runi et al., 2017) stated that competence has no effect on employee performance.

Motivation is a process to activate motives into actions or behavior to meet needs and achieve goals or circumstances and readiness in individuals who encourage their behavior to do something in achieving goals (Abdi, 2012). Acording to (Sedarmayanti's, 2017); (Mangkunegara, 2015), (Gardjito et al., 2014) and (Rahsel, 2016); (Razak, 2021); (Alam et al., 2021) and (Verawati et al., 2021) showed that motivation had an effect on performance, while (Hasmalawati, 2018) and (Dhermawan et al., 2012) stated that motivation had no effect on performance.

Education is an effort to foster and develop the human personality either in the spiritual or in the physical. With education we can be more mature because education has a very positive impact on us, and also education can eradicate illiteracy and will provide skills, mental abilities, and so on. Education affects employee performance (Juliana et al., 2015 and Mandang et al., 2017), while (Koni, 2018) in his research shows that education has no effect on performance.

(Husain, 2013) states that job satisfaction is a person's feelings and assessment of his work, especially regarding his working conditions, in relation to whether his work is able to meet his expectations, needs, and desires. (Indrawati, 2013) and (Makawide et al., 2017); who examined the effect of satisfaction on performance stated that job satisfaction had a positive effect on performance, while (Windari et al., 2014) in their research stated that satisfaction had no effect on performance.

This research difference is the basis of this research and it can be said that this research uses a research gap, so it is necessary to do research again in solving the existing issues. The difference between this research and previous research is in the sample of the research conducted. The sample used in the previous study were permanent employees in several companies, while this study used a sample of outsourced employees. 


\section{THEORITICAL REVIEW}

Employee performance. Performance is the result of a series of process activities carried out to achieve certain organizational goals. Acording to (Isvandiari, 2017) says that performance is the result obtained by an organization, both profit-oriented and non-profitoriented organizations that are produced over a period of time. (Siagian, 2017) states that in general performance measurement is translated into an assessment of work behavior in general, then translated into basic work behavior which includes work quantity, work quality, knowledge about work, opinions or statements submitted, decisions taken, work planning, and area of work organization. Employee performance indicators are used as indicators that measure employee performance individually. Robbins \& Judge (2017) there are 6 indicators that can be used to measure employee performance, including: 1. Quality. 2. Quantity. 3. Punctuality. 4. Effective Use of Resources. 5. Independent. and 6. Committed

Job satisfaction. Each employee individually has different job satisfaction, even though they are in the same type of job, this depends on the level of their needs and the system that applies to them. Acording to (Handoko, 2015) states that job satisfaction is a pleasant or unpleasant emotional state in which employees view their work. (Hasibuan, 2015) states that there are types of employee satisfaction at work, such as: Enjoying his job, Loving his job, Morale, Discipline, Work performance. (Mangkunegara, 2015) states that there are five theories of job satisfaction, including: balance theory, difference theory, needs fulfillment theory, group view theory, and two-factor theory. (Wibowo, 2013) states that there are two approaches that are widely used to measure job satisfaction, namely: 1) Single global rating, which is nothing but asking individuals to respond to one question, such as by considering all things. 2) Summation score, which identifies key elements in the job and asks employees how they feel about each element.

Competence. Acording to (Muhaimin, 2014), competence is a set of responsible intelligent actions that must be possessed by a person as a condition to be considered capable of carrying out tasks in certain fields of work. (Gulo, 2010) argues that competence consists of two interacting aspects, namely the visible aspect or the so-called performance and the invisible aspect or the so-called rational aspect. Performance is shown in the form of behavior that can be demonstrated so that it can be seen, observed and felt. While the rational aspect cannot be observed because it does not appear in the form of empirical behavior. Several aspects contained in the concept of competence (Sutrisno, 2011): Knowledge, Understanding, Ability (skills), Values, Attitude (interest). Dimensions of competence in this study, namely: knowledge, skills, abilities and understanding

Motivation. (Sutrisno, 2011), motivation is a factor that encourages a person to carry out certain activities, therefore motivation is often interpreted as a factor driving a person's behavior. (Rivai and Sagala, 2011), the stronger the work motivation, the higher the employee's performance. this means that every increase in employee motivation will provide a very significant increase for employee performance. (Siagian, 2017), there are 7 
indicators of work motivation, namely: 1. Driving Force, 2. Willingness. 3. Building Expertise. 4. Building Skills. 5. Responsibility. 6. Obligations. and 7. Goals.

Education. According to the National Education System Law No. 20 of 2003, education is a conscious and planned effort to create a learning atmosphere and learning process so that students actively develop their potential to have religious spiritual strength, self-control, personality, intelligence, noble character, and the necessary skills. himself and society. (Wirawan et al., 2019), education indicators are: a. Formal education is the last education completed by each worker which includes elementary, junior high, high school and college. b. Informal education is the attitude and personality that is formed from the family and the environment. Formal education is the last education completed by each worker which includes elementary, junior high, high school and college.

From the description above, the hypothesis formulated in this study are: 1) Competence affects on Satisfaction; 2) Motivation affects on Satisfaction; 3) Education affects on satisfaction; 4) Competence affects on Performance; 5) Motivation affects on Performance; 6) Education affects on performance; 7) Satisfaction affects on performance

\section{METHODS}

In this study the approach used is a quantitative approach. In the end, the results of this study explain the causal relationship between the variables through hypothesis testing. This study aims to determine the relationship between five variables, namely competence (C1), motivation (M2), education (E3), and performance (P2) and satisfaction (S1).

Population is a generalization area consisting of objects/subjects that have certain qualities and characteristics determined by the researcher to be studied and then draw conclusions. The population in this study is alumni of the University of Semarang who are already working, where the number is unknown because there has not been a comprehensive search of alumni by the University of Semarang. The amount is unknown. Furthermore, Sugiono also explained the sample, where the sample is part of the number and characteristics possessed by the population. The sample is determined by the researcher based on consideration of the problem, objectives, hypotheses, methods, and research instruments, in addition to considerations of time, effort, and financing. In sampling, if the sampling is not in accordance with the quality and characteristics, it can cause the research to become ordinary, or even unreliable and in making conclusions errors can occur.

The sampling technique used in this research is non-probability sampling. Nonprobability sampling is a sampling technique that does not provide equal opportunities/opportunities for each element or member of the population to be selected as a sample. The method used in sampling is purposive sampling. In the technique of determining this sample by carrying out certain considerations made by the researcher. The purpose of doing sampling intentionally on a population is to represent the characteristics of the population that will be used in research later. The criteria/considerations for the sample are: Graduated from the University of Semarang and have worked for a maximum of 3 years. The number of samples for the unknown population is carried out using the following formula (Suharsimi Arikunto, 2002) and found the number of samples as many 
as 96 respondents.

Research Instruments. Data was collected through a questionnaire method, namely providing a list of questions/questionnaires to students/alumni who were selected as respondents. The list of questions is distributed to Semarang University alumni who are already working in the company. The analytical method used is SEM (Structural Equation Model) where PLS 3.0 software is used.

Table 1. Variables and Indicators

\begin{tabular}{|c|c|}
\hline Variable & Indicator \\
\hline Competence & Knowledge, Skills, Ability, Understanding \\
\hline Motivation & Drive to achieve goals, Morale, Initiative, Sense of Responsibility \\
\hline Education & $\begin{array}{l}\text { Last Education, Informal education from the family, Informal education from the } \\
\text { environment }\end{array}$ \\
\hline Satisfaction & Loyalty, Ability, Honesty, Creativity, Leadership \\
\hline Performance & Quantity, Timeliness, Effectiveness, Resource Usage, Independent \\
\hline
\end{tabular}

Management of data in this study will use software smartPLS 3.2.7. In this study, the Likert scale was used as the measurement scale (1 to 5)

\section{RESULTS}

Table 2. Convergent Validity

\begin{tabular}{|c|c|c|c|c|c|}
\hline & Satisfaction & Performance & Competence & Motivation & Education \\
\hline $\mathrm{C} 1.1$ & & & 0,796 & & \\
\hline $\mathrm{C} 1.2$ & & & 0,862 & & \\
\hline C1.3 & & & 0,893 & & \\
\hline $\mathrm{C} 1.4$ & & & 0,768 & & \\
\hline M2.1 & & & & 0,737 & \\
\hline M2.2 & & & & 0,838 & \\
\hline M2.3 & & & & 0,821 & \\
\hline M2.4 & & & & 0,815 & \\
\hline E3.1 & & & & & 0,901 \\
\hline E3.2 & & & & & 0,915 \\
\hline E3.3 & & & & & 0,805 \\
\hline S 1.1 & 0,707 & & & & \\
\hline $\mathrm{S} 1.2$ & 0,786 & & & & \\
\hline $\mathrm{S} 1.3$ & 0,777 & & & & \\
\hline S1.4 & 0,824 & & & & \\
\hline S1.5 & 0,754 & & & & \\
\hline $\mathrm{P} 2.1$ & & 0,790 & & & \\
\hline $\mathrm{P} 2.2$ & & 0,753 & & & \\
\hline
\end{tabular}


Nurhidayati, Kusnilawati, and Santoso: Employee Satisfaction:...

\begin{tabular}{ll}
\hline P2.3 & 0,817 \\
P2.4 & 0,740 \\
P2.5 & 0,774 \\
P2.6 & 0,713 \\
\hline
\end{tabular}

Table 2 explains that all indicators of variables competence (C1), motivation (M2), education (E3), and performance (P2) and satisfaction (S1) have an outer loading greater than 0.5 , which means that all indicators are valid.

Table 3. Average variance extracted (AVE)

\begin{tabular}{lc}
\hline & $\begin{array}{c}\text { Average Variance } \\
\text { Extracted (AVE) }\end{array}$ \\
\hline Satisfaction & 0.594 \\
Performance & 0.586 \\
Competence & 0.691 \\
Motivation & 0.646 \\
Education & 0.766 \\
\hline
\end{tabular}

Table 3 explains that AVE value for the Satisfaction variable is 0.594 , the Performance variable is 0.586 , the Competency variable is 0691, the motivation variable is 0.646 and the education variable is 0.766 . At the critical limit of 0.5 , the indicators in each construct are valid with other items in one measurement.

Table 4. Composite Reliability dan Cronbach's Apha

\begin{tabular}{lcc}
\hline & Cronbach's Alpha & $\begin{array}{c}\text { Composite } \\
\text { Reliability }\end{array}$ \\
\hline Satisfaction & 0.831 & 0.879 \\
Performance & 0.859 & 0.894 \\
Competence & 0.850 & 0.899 \\
Motivation & 0.817 & 0.879 \\
Education & 0.848 & 0.907 \\
\hline
\end{tabular}

Table 4 explains that a construct is declared reliable if it has a composite reliability value above 0.70 and Cronbach's alpha above 0.60. From the results of the SmartPLS output above, all constructs have a composite reliability value above 0.70 and Cronbach's alpha above 0.60 . So it can be concluded that the construct has good reliability. 
Nurhidayati, Kusnilawati, and Santoso: Employee Satisfaction:...

Table 5. R-Square

\begin{tabular}{lcc}
\hline & R Square & R Square Adjusted \\
\hline Satisfaction & 0,322 & 0,300 \\
Performance & 0,498 & 0,476 \\
\hline
\end{tabular}

Table 5 explains that value of R2 $=1-(1-0.300)(1-0.476)=0.6332$, meaning that the model is able to explain the phenomenon of Employee Performance of 63.32 percent, while the remaining 36.68 percent explained by other variables. R2 value small means ability independent variables in explaining the variation of the dependent variable is very limited. A value close to one means that the independent variable gives almost all of thethe information needed to predict the variation of the dependent variable (Ghozali, 2013)

Inner Model Test or Structural Model Test

This test is used to evaluate the relationship between latent constructs as hypothesized in the study. Based on the PLS output, the following figure is obtained

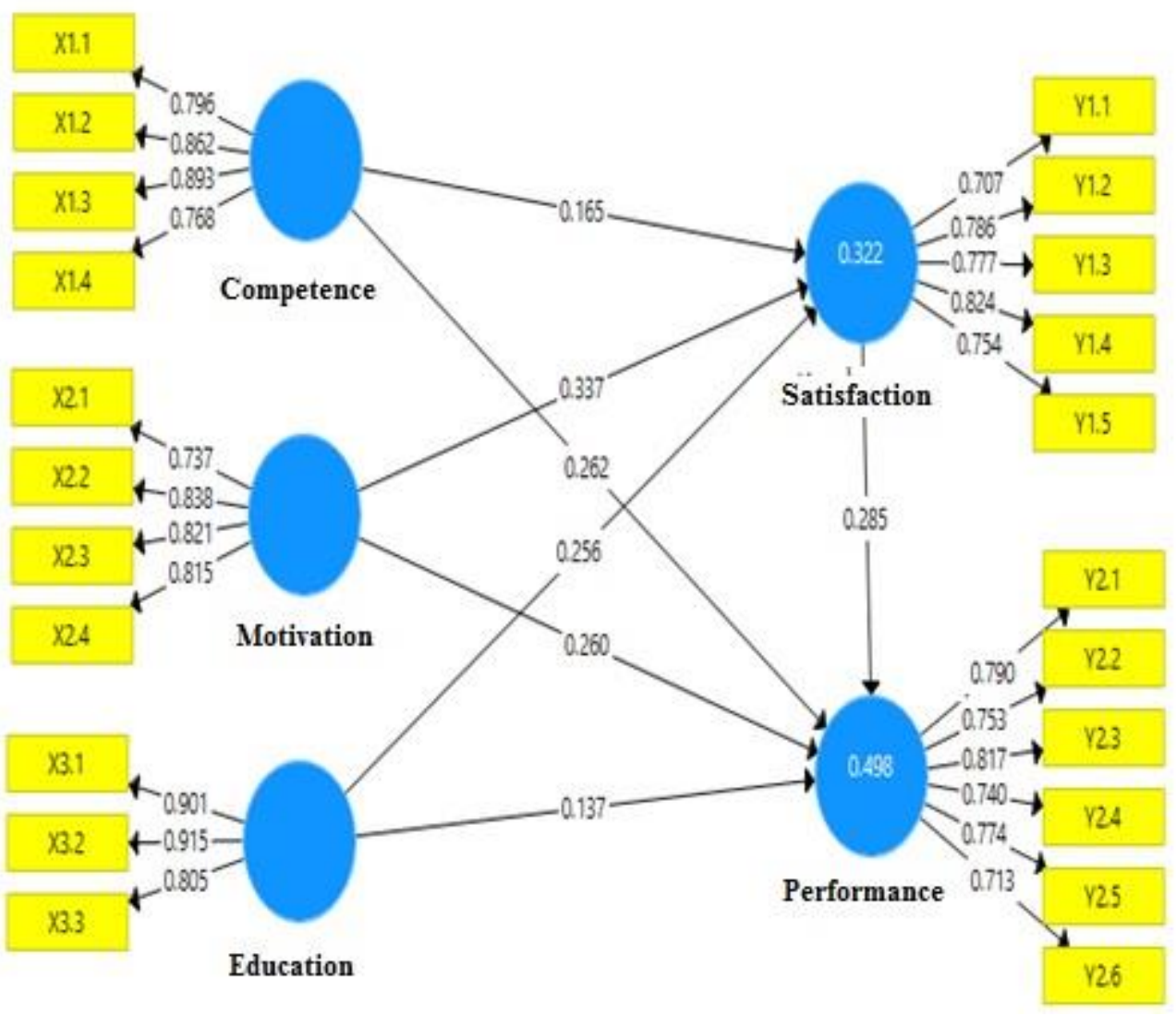

Figure 1. PLS Output Output 
The figure 1 explains that Path Coefficients (Mean, STDEV, t-Value) can be arranged as in the table below.

Table 6. Path Coefficients (Mean, STDEV, t-Value)

Test Results $\mathrm{t}$

\begin{tabular}{lccccc}
\hline & $\begin{array}{c}\text { Original } \\
\text { Sample } \\
(\mathbf{O})\end{array}$ & $\begin{array}{c}\text { Sample } \\
\text { Mean (M) }\end{array}$ & $\begin{array}{c}\text { Standard } \\
\text { Deviation } \\
(\text { STDEV) }\end{array}$ & $\begin{array}{c}\text { T Statistics } \\
(|\mathbf{O S T D E V}|)\end{array}$ & P Values \\
\hline Satisfaction -> Performance & 0.285 & 0.280 & 0.080 & 3.574 & 0.000 \\
Competence -> Satisfaction & 0.165 & 0.170 & 0.107 & 1.539 & 0.125 \\
Competence -> Performance & 0.262 & 0.265 & 0.100 & 2.619 & 0.009 \\
Motivation -> Satisfaction & 0.337 & 0.341 & 0.103 & 3.268 & 0.001 \\
Motivation -> Performance & 0.260 & 0.268 & 0.084 & 3.087 & 0.002 \\
Education -> Satisfaction & 0.256 & 0.269 & 0.083 & 3.072 & 0.002 \\
Education -> Performance & 0.137 & 0.138 & 0.081 & 1.702 & 0.089 \\
\hline
\end{tabular}

Based on Figure 1 and Table 6 above, it can be explained as follows:

Satisfaction -> Performance. It can be seen that the original sample value of the Satisfaction estimate is 0.285 with a significance below $5 \%$ as indicated by the t-statistical value of $3.574>\mathrm{t}$-table of 1.661 . The positive original sample estimate value indicates that satisfaction has a positive effect on performance.

Competence $->$ Satisfaction. It can be seen that the original sample competency estimate value is 0.165 with a significance above $5 \%$ as indicated by the t-statistic value of $1.539<\mathrm{t}$-table value of 1.661 . The original sample estimate value is positive indicating that competence has no effect on satisfaction.

Competence $\rightarrow$ Performance. It can be seen that the value of the original sample estimate of competence has a positive effect on performance. The test results can be seen from table 4.9 above, competence obtains the original sample estimate value of 0.262 with a t-statistic value of $2.619>1.661$ which means that competence has a positive effect on performance with a significance level above $5 \%$.

Motivation -> Satisfaction. It can be seen that the original sample estimate of motivation is 0.285 with a significance below $5 \%$ as indicated by the $t$-statistical value of $3.574>$ the t-table value of 1.661 . The positive original sample estimate value indicates that motivation has a positive effect on satisfaction

Motivation -> Performance. It can be seen the value of the original sample estimate of motivation on performance. Based on the results of the motivation test, the original sample estimate value of 0.260 with a t-statistic value of $3.087>1.661$ tcount $>$ ttable means that the motivation affects performance is accepted.

Education -> Satisfaction. Competence obtains an original sample estimate value of 0.262 with a t-statistic value of $2.619>1.661$ which means that education has a positive effect on satisfaction with a significance level above $5 \%$ (significant)

Education -> Performance/ It can be seen that the original sample estimate value of Education is 0.256 with a t-statistic value of $3.072>1.661$ tcount $>$ ttable means the sixth hypothesis which says that education affects performance 


\section{DISCUSSION}

The Effect of Competence on Satisfaction. The estimated value of the original sample is positive which indicates that competence has no effect on satisfaction, so the first hypothesis is rejected. Competence is knowledge, skills, and abilities that are mastered by someone who has become a part of him, so that he can perform cognitive, affective, and psychomotor behavior as well as possible. In this study, competence is seen from 4 indicators, namely: Knowledge, Skills, Ability and Understanding. As for the results of filling out the respondents' questionnaires, it turns out that the knowledge indicator occupies the highest number compared to the other three indicators. They conclude that competence does not have a close relationship with knowledge, the higher the level of knowledge it is possible that it will not further increase their competence, because having high knowledge cannot guarantee job satisfaction compared to job skills. This is not in accordance with the opinion expressed by (Lawler, 2004) that competence affects job satisfaction and ultimately has implications for performance and acts as feedback that causes employees to adjust their behavior. The results of this study are supported by the research of (Runi et al., 2017) with the title: The Effect of Leadership, Motivation, Competence, Commitment to Satisfaction and Lecturer Performance at Private Higher Education Kopertis Region IX South Sulawesi Province, stating that competence has no effect on job satisfaction, however, The results of this study are contrary to the results of research by (Amador et al., 2006) which states that competence actually affects job satisfaction.

The Effect of Motivation on Satisfaction. The Effect of Motivation on Satisfaction. The positive original sample estimate value indicates that motivation has a positive and significant effect on satisfaction, so the second hypothesis is accepted. Motivation is a factor that encourages someone to do certain activities, therefore motivation is often interpreted as a factor driving a person's behavior. In this study, motivation is seen from 4 indicators, namely encouragement to achieve goals, work enthusiasm, initiative and a sense of responsibility. As for the results of filling out the respondent's questionnaire, it turns out that the indicator of encouragement to achieve goals occupies the highest number compared to the other three indicators. They are of the view that by creating a comfortable work environment with the aim that they can work more optimally, with the attention of the organization and good relations can provide job satisfaction. The results of this study are in accordance with the research of (Juniari et al., 2015) and (Deswarta, 2017) who concluded that motivation has a significant effect on job satisfaction. However, the results of this study contradict the results of research by (Noor and Zainordin, 2018) which shows that motivation actually has an insignificant effect on job satisfaction.

The Effect of Education on Satisfaction. The third test was conducted to see whether education had a positive and significant effect on satisfaction. The test results can be seen that education has a positive effect on satisfaction with a significance level above 5\% (significant), then the third hypothesis is accepted. Education is a conscious and planned effort to create a learning atmosphere and learning process so that students actively develop their potential to have religious spiritual strength, self-control, personality, 
intelligence, noble character, and skills needed by themselves and society. In this study, education is seen from 3 indicators, namely: Recent Education, Informal Education from the Family, Informal Education, and Environment. As for the results of filling out the respondent's questionnaire, it turns out that the latest education indicator occupies the highest number compared to the other two indicators. They think that the last education is so important because the last education is a basic need for working according to their level of education, and if higher education then they will get a job that matches their education level and few doors are open to a better career and job satisfaction. Moreover, if they occupy certain positions because of their latest education, if there is a higher formation, they definitely need to add higher education. The results of this study are in accordance with the results of (Puspaningsih, 2004) which states that education affects satisfaction. However, the results of this study contradict the results of Pakpahan's research, (Sukanto, 2014) which found that the level of education had an effect but not significantly on employee performance.

The Effect of Competence on performance. Competence has a positive and significant effect on performance with a significance level above 5\%, so hypothesis 4 is accepted. Competence as a personal aspect of an employee that allows him to achieve superior performance. These personal aspects include traits, motives, value systems, attitudes, knowledge, and skills. Competence will direct behavior, while behavior will produce performance. In this study, competence is seen from 4 indicators, namely: Knowledge, Skills, Ability and Understanding. As for the results of filling out the respondents' questionnaires, it turns out that the knowledge indicator occupies the highest number compared to the other three indicators. They conclude that competence has a close relationship with knowledge, the higher the level of knowledge, the more it increases competence, because having high knowledge can guarantee its performance compared to other indicators. This is in accordance with the opinion expressed by (Lawler, 2004) that competence affects performance and can act as feedback that causes employees to adjust their behavior. The results of this study support the research of (Septiyani and Sanny, 2013); and (Runi et al., 2017) who examined the effect of competence on employee performance stated that competence had no effect on employee performance, on the contrary, (Kartika and Sugiarto, 2014), (Manik and Wiarah, 2014); (Deswarta, 2017); (Alam et al.,, 2021) and (Darman and Adha, 2021) state that competence has an effect on performance.

The Effect of motivation has an effect on performance. The influence of motivation has an effect on performance. The fifth hypothesis which states that motivation has a positive and significant influence on performance is accepted. Motivation is an internal and external drive within an individual caused by interests and desires, drives, needs, hopes, ideals, and goals. In this study, motivation is seen from 4 indicators, namely encouragement to achieve goals, work enthusiasm, initiative and a sense of responsibility. As for the results of filling out the respondent's questionnaire, it turns out that the indicator of encouragement to achieve the goal occupies the highest number compared to the other three indicators. Motivation itself is something that can make someone do 'something'. They have a positive psychological drive, it will produce good behavior, then the level of 
effort or encouragement to achieve the goals given at work is also good, and being persistent about a problem at work will improve their performance. This is in accordance with research conducted by (Sedarmayanti, 2017); (Mangkunegara, 2015), (Gardjito et al., 2014); (Rahsel, 2016); (Razak, 2021); (Alam et al., 2021) and (Verawati et al., 2021) showed that motivation had an effect on performance, while (Hasmalawati, 2018) and (Dhermawan et al., 2012) stated that motivation had no effect on performance.

The Effect of Education on Performance. Effect of Education on Performance. Education has a positive and significant impact on acceptable performance. Education is a process of changing the attitudes and behavior of a person or group of people in an adult manner through teaching and practice. With education we can be more mature because this education has a very positive impact on us, and education can eradicate illiteracy and will provide skills, mental abilities, and so on. In this study, education is seen from 3 indicators, namely: Recent Education, Informal Education from the Family, Informal Education, and Environment. As for the results of filling out the respondent's questionnaire, it turns out that the latest education indicator occupies the highest number compared to the other two indicators.

They think that the last education is so important because the last education is a basic need for working according to their level of education, and if they have higher education, they will get jobs that match their education level and few doors are open for a better career. Human resources or employees who occupy a certain position, do not necessarily have the abilities that are in accordance with the requirements needed in that position. This happens because people often occupy certain positions not because of their abilities, but because of the availability of formations. Therefore, it is necessary to increase their higher education. This is in accordance with the research of (Juliana et al., 2015) and (Mandang et al., 2017) which stated that education had an effect on employee performance, while (Koni, 2018) in his research showed that education had no effect on employee performance.

The Effect of Satisfaction on Performance. The positive original sample value indicates that satisfaction has a positive and significant effect on performance, so the seventh hypothesis is accepted. Work goals are one of the most important things in an organization. This is because job satisfaction can affect work behaviors such as: lazy, diligent, productive, etc. or have a relationship with some types of behavior that are very important in the organization. In this study, satisfaction is seen from 5 indicators, namely: Loyalty, Ability, Honesty, Creativity and Leadership. As for the results of filling out the respondent's questionnaire, it turns out that the ability indicator is the highest compared to the other four indicators. Those with a high level of ability will have an impact on high job satisfaction, so that they have positive feelings about the job and lead to an increase in their performance. Therefore, the higher job satisfaction is obtained and felt, the more likely it is to provide the best performance. Vice versa, if you do not get satisfaction, it will be difficult to provide the best performance. (Indrawati, 2013) and (Makawide et al., 2017); who examined the effect of satisfaction on performance stated that job satisfaction had a positive effect on performance, while (Windari et al., 2014) in their research stated that satisfaction had no effect on performance, 


\section{CONCLUSION}

Competency variable has no effect on satisfaction, this is indicated by the value of $t$ count $<\mathrm{t}$ table and sig $>0.05$. Motivation variable has an effect on satisfaction, which is indicated by $\mathrm{t}$ count which is greater than $\mathrm{t}$ table and sig $<0.05$, it shows that the higher someone is motivated, the more satisfaction is obtained. Education variable has an effect on satisfaction, which is indicated by $t$ count which is greater than $t$ table and sig $<0.05$, this indicates that if employees have high education, they will also feel satisfied. Competency variable has an effect on performance, which is indicated by $\mathrm{t}$ arithmetic which is greater than $t$ table and sig $<0.05$, this shows that the more employees have competence, the better their performance. Motivation variable has an effect on performance, which is indicated by $t$ count which is greater than $t$ table and sig $<0.05$, this shows that if employees are motivated, their performance is also getting better. Education variable has an effect on performance, which is indicated by $t$ count which is greater than $t$ table and sig $<0.05$. This shows that the more educated employees are, the better their performance will be. Satisfaction variable has an effect on performance, which is indicated by $t$ arithmetic which is greater than $t$ table and sig $<0.05$, this shows that if employees are satisfied, the performance is also getting better.

Implication. Based on the conclusions of the research, it can be conveyed things which are theoretical implications (implications that are related to the contribution of research to the development of scientific knowledge) and applied implications (implications that include useful suggestions for practitioners).

Theoretical Implications. Acording to (Septiyani and Sanny, 2013) and (Runi et al., 2017) that competence is not a predictor of employee performance which states that competence has no effect on employee performance, on the contrary according to (Kartika and Sugiarto, 2014), (Manik and Wiarah, 2014); (Deswarta, 2017); (Alam et al., 2021) and (Darman and Adha, 2021) state that competence has an effect on performance.

Acording to (Sedarmayanti, 2017); (Mangkunegara, 2015), (Gardjito et al., 2014); (Rahsel, 2016); (Razak, 2021); (Alam et al., 2021) and (Verawati et al., 2021) showed that motivation had an effect on performance, while (Hasmalawati, 2018) and (Dhermawan et al., 2012) stated that motivation had no effect on performance.

Acording to (Juliana et al, (2015) and (Mandang et al., 2017) which state that education affects employee performance, while Koni (2018) in his research shows that education has no effect on employee performance.

(Acording to Indrawati, 2013) and (Makawide et al., 2017); who examined the effect of satisfaction on performance stated that job satisfaction had a positive effect on performance, while (Windari et al., 2014) in his research stated that satisfaction had no effect on performance. non-profit organizations such as government and universities, and create differences between one company and another.

This research provides a new color in the repertoire of research on the influence of competence, motivation, education and satisfaction on performance. The person's new management is not all things that exist in internal factors from within, such as: competence, motivation and results are the same as research on management science 
development organizations, especially Human Resources, the development and improvement of HR in organizations is very much needed because HR is a assets in the organization, for that it needs to be developed in order to improve the quality and answer the needs of the organization and society in general.

Applied Implication. Based on the conclusions and implications that have been described, then applied development is developed which is expected to be able to contribute to the theory of management. Applied implications can be derived from the theory built and based on research that has been carried out. From the results of this study, several company policies where alumni of the University of Semarang can be suggested, namely: (1) In terms of competence, the company needs to develop training owned by employees, namely by holding workshops or involving employees in trainings that can improve their competence. (2) In terms of motivation, based on the results of descriptive statistical tests of motivation, companies need to increase the motivation of employees to try and compete in achieving good positions. Companies also need to strive to maintain the motivation of employees to remain good and stable, for that it is necessary to pay attention to matters relating to motivation itself. For example, if an employee who has a certain achievement is given an award in the form of material or immaterial so that the employee will be encouraged to achieve certain achievements, and motivate other co-workers. (3) In terms of education level, it is necessary to optimize human resources by following career development so that the qualifications of company employees are further improved to produce better quality work. In addition, companies need to provide opportunities for employees to continue their education to a higher level and employees to follow clear career development.

\section{REFERENCES}

Abdi,U.R. (2012). Metodologi Penelitian Sosial dan Ekonomi, Bandung : Alfabet

Alam, S., Fajriah, Y., Hamiddin, M. I. N. dan Jumady, E. (2021). Menciptakan Budaya Perilaku Kewarganegaraan Organisasi dan Kinerja Melalui Optimasi Riset Manusia. Jurnal Manajemen UNTAR. XXV(03). 479-498. DOI: http://dx.doi.org/10.24912/jm.v25i3.762.

Amador, L.B., Nicolas, A.L and Villa, L.E, (2006). Education and Competence Mismatches : Job Satisfaction Consequences for Workers. XVI Jornadas ASEPUMA - IV Encuentro International, 6(1):.1-12.

Arikunto, S. (2016). Prosedur Penelitian: Suatu Pendekatan Praktik. Jakarta: Rineka Cipta.

Darman, D. dan Adha, W. M. (2021). Pengaruh Kecerdasan Intelektual dan Kecerdasan Emosional Terhadap Kompetensi dan Kinerja Pegawai. Jurnal Manajemen UNTAR. XXV(02), 222-239 DOI: http://dx.doi.org/10.24912/jm.v25i2.737

Dhermawan, A. A. N. B., Sudibya, I. G. A. dan Utama, I. W. M. (2012). Pengaruh Motivasi, Lingkungan Kerja, Kompetensi, Dan Kompensasi Terhadap Kepuasan Kerja Dan Kinerja Pegawai Di Lingkungan Kantor Dinas Pekerjaan Umum Provinsi Bali. Jurnal Manajemen, Strategi Bisnis, dan Kewirausahaan. 6(2). 173-184. 
Deswarta. (2017). Pengaruh Kompetensi dan Motivasi terhadap Kepuasan kerja dan Kinerja Dosen Fakultas Tarbiyah dan Keguruan Uin Syrif Kasim Riau. Jurnal Valuta, 3(1). 19-39.

Gardjito, A. H., Musadieq, M. A, dan Nurtjahjono, G. E. (2014). Pengaruh Motivasi Kerja, dan Lingkungan Kerja Terhadap Kinerja Karyawan (studi pada Karyawan Bagian Produksi PT. Karmand Mitra Andalan Surabaya). Jurnal Administrasi Bisnis (JAB). 13(1). 26-39

Gulo. (2010). Metodologi Penelitian. Jakarta: Grasindo

Handoko (2017). Manajemen Sumber Daya Manusia. Edisi Revisi. Jakarta : Bumi Aksara

Hasibuan, M. S. P. (2019). Manajemen: Dasar, Pengertian, dan Masalah. Jakarta : Bumi Aksara.

Hasmalawati, N. (2018).Pengaruh Kualitas Kehidupan Kerja Dan Motivasi Kerja Terhadap Kinerja Karyawan. Jurnal Solusi.10(1). 26-35.

Husein, U. (2011). Metode Penelitian Untuk Skripsi dan Tesis Bisnis. Edisi 11. PT Jakarta : Raja Grafindo Persada.

Indrawati, A.D. (2013). Pengaruh Kepuasan Kerja Terhadap Kinerja Karyawan dan Kepuasan Pelanggan pada Rumah Sakit Swasta di Kota Denpasar. Jurnal Manajemen, Strategi Bisnis, dan Kewirausahaan. 7(2), 153-142.

Isvandiari, A. dan Fuadah, L..(2017). Pengaruh Kompensasi dan Disiplin Kerja Terhadap kinerja Karayawan PG.Meritjan, Kediri, 2012. Jurnal JIBEKA, 11(1). 2-8.

Juliana, Hakim, L. dan Mustari, N.. (2015). Pengaruh Tingkat Pendidikan Terhadap Kinerja Pegawai Di Badan Perencanaan Pembangunan Daerah Kabupaten Enrekang. Kolaborasi : Jurnal Administrasi Publik, 1(1). 11-19.

Juniari, N. K. E., Riana, I. G. dan Subudi, M. (2015). Pengaruh Motivasi Terhadap Kepuasan Kerja Dan Kinerja Pegawai Negeri Sipil (Pns) Di Sekolah Tinggi Pariwisata Nusa Dua Bali. E-Jurnal Ekonomi dan Bisnis Universitas Udayana. 4(11). 823-840.

Kartika, L. N. dan Sugiarto, A. (2014). Pengaruh tingkat kompetensi terhadap kinerja pegawai administrasi perkantoran. Jurnal Ekonomi dan Bisnis (JEB). 17(1). 73-90.

Koni, W. (2018). Pengaruh Tingkat Pendidikan Dan Motivasi Kerja Terhadap Kinerja Dosen Iain Sultan Amai Gorontalo. Jurnal Al-Buhuts. 1(1), 52-72.

Lawler, E. E. (2011). Dampak kinerja terhadap kepuasan kerja. Editor Usmara dalam Handbooks of organization. Yoqyakarta: Amara books.

Makaluas, C. G., Pio, R. J. dan Sumampouw, H. J. (2017). Pengaruh Kepuasan Kerja Terhadap Kinerja Karyawan Pada Pt Bpr Prisma Dana Manado. Jurnal Administrasi Bisnis Unsrat. 5(005). 1-8.

Mandang, E.F., Lumanauw, B. dan Walangitan, M.D.B. (2017) Pengaruh Tingkat Pendidikan Dan Pelatihan Terhadap Kinerja Karyawan Pada Pt. Bank Rakyat Indonesia (Persero), Tbk Cabang Manado. Jurnal EMBA. 5(3). 4324-4335.

Mangkunegara, A. P. (2015). Sumber Daya Manusia Perusahaan. Cetakan kedua belas. Bandung : Remaja Rosdakarya.

Manik, E., dan Wiarah. (2014). Pengaruh Kompetensi Dan Kompensasi Terhadap Kepuasan Kerja Serta Implikasinya Pada Kinerja Paramedis Di Rumah Sakit Cibabat Kota Cimahi. Jurnal Ekonomi, Bisnis \& Entrepreneurship. 8(2). 62-72.

Muhaimin, A. A. (2014). Pendidikan Yang Membebaskan. Jogjakarta : Ar Ruzz Media. 
Noor, S.N.A.M, and Zainordin, N. (2018). The Impact Of Motivation On Job Satisfaction In A Quantity Surveying Consultant Firm. Proceeding International Conference On Global Business and Social Sciences(ICGBSS) eISBN 978-967-14841-9-7.

Puspaningsih, A. (2004). Faktor-faktor yang Beerpengaruh Terhadap Kepuassan kerja dan Kinejra Manager Perusahaan Manufafktur. JAAI. 8(1). 65-80.

Rahsel, Y. (2016). Pengaruh Motivasi Kerja Terhadap Kinerja Pegawai Administrasi Pusat Universitas Padjajaran Bandung (Studi Pada Bagian Administrasi Umum UNPAD). Jurnal Manajemen Magister. 02(02). 208-220.

Razak, N. (2021). Bagaimana Self-Efficacy Mendorong Kinerja Pekerjaan: Peran Pekerjaan Kecemasan dan Motivasi Intrinsik Jurnal Manajemen UNTAR. XXV(02). 190-205.

Runi, I., Ramli, M., Nujum, S., and Kalla, R. (2017). Influence Leadership, Motivation, Competence, Commitment To Satisfaction And Performance Lecturer At Private Higher Education Kopertis Region IX In South Sulawesi Province. Journal of Business and Management (IOSRJBM), 19(7), 56-67.

Rivai, V. dan Sagala, E. J.. (2011). Manajemen Sumber Daya Manusia untuk Perusahaan dari Teori ke Praktik. Jakarta: PT Raja Grafindo.

Robbins, P. S. and Judge, T. A. (2017). Organizational Behaviour, Edisi 13, Jilid 1, Jakarta : Salemba Empat.

Sedarmayanti. (2017). Perencanaan dan Pengembangan SDM untuk Meningkatkan Kompetensi, Kinerja dan Produktivitas Kerja. Bandung : PT Refika Aditama.

Septiyani dan Sanny, L. (2013). Analisis Pengaruh Kompetensi Individu Dan Motivasi Terhadap Kinerja Karyawan PT. Beta Setia Mega. Binus Business Review. 4(1). 274282

Siagian, M.. (2017). Analisis Budaya Organisasi, Disiplin Kerja, dan Pengembangan Sumber Daya Manusia Terhadap Kinerja Pegawai Dengan Motivasi Kerja Sebagai Variabel Intervening Di Kantor Pemerintahan Kecamatan Lubuk Baja Batam. Jurnal AKBAR JUARA, 2(3). 25-39.

Spencer, N.Lyle \& Spencer, M. Signe. (1993). Competence at Work: Models for Superrior Performance. New York : John Wily \& Son,Inc .

Sutrisno, E. (2011). Manajemen Sumber Daya Manusia. Jakarta: Kencana.

Verawati, D. M., Achsa, A. dan Novitaningtyas, I. (2021). Menelaah Model Kinerja Sumber Daya Manusia di Destinasi Wisata Setelah Pandemi. Jurnal Manajemen UNTAR. XXV(02), 175-189.

Wibowo. (2018). Manajemen Kinerja. Jakarta : Rajawali Pres.

Windari, A., Wilujeng, S. dan Suryaningtyas, D. (2014). Pengaruh Kepuasan Kerja Dan Disiplin Kerja Terhadap Kinerja Karyawan Pt. Pos Indonesia (Persero) Malang. Jurnal Riset Mahasiswa Manajemen. 2(1). 1-10.

Wirawan, K.E., Bagia, I.W, dan Susila, G. P. A. J. (2019). Pengaruh Tingkat Pendidikan dan Pengalaman Kerja terhadap Kinerja Karyawan. E-Jurnal Bisma Universitas Pendidikan Ganesha Jurusan Manajemen, 5(1), 60-67. 